Penelitian

\title{
Prevalensi Kecacingan pada Anjing dan Kucing di Klinik Smilevet Kelapa Gading Periode Januari 2020 - Januari 2021
}

\author{
(Prevalence Helminthiasis in Dogs and Cats at Smilevet Clinic Kelapa Gading \\ for Period January 2020 - January 2021) \\ Maria Natasya', Ridi Arif ${ }^{2}$, Risa Tiuria ${ }^{2}$, \\ Didit Triatmojo ${ }^{3}$, Aurilia Hemas Adytia Wardaningrum³ \\ ${ }^{1}$ Mahasiswa Program Sarjana, Fakultas Kedokteran Hewan, Institut Pertanian Bogor \\ ${ }^{2}$ Divisi Parasitologi dan Entomologi Kesehatan, Departemen Ilmu Penyakit Hewan \\ dan Kesehatan Masyarakat Veteriner, Institut Pertanian Bogor \\ ${ }^{3}$ Dokter Hewan Klinik Smilevet Kelapa Gading \\ *Penulis untuk korespondensi: ridiarif88@apps.ipb.ac.id \\ Diterima 16 Juli 2021, Disetujui 26 Oktober 2021
}

\begin{abstract}
ABSTRAK
Anjing dan kucing merupakan hewan yang hidup berdampingan dengan manusia baik sebagai hewan peliharaan. Infeksi parasit cacing merupakan masalah yang umum pada hewan peliharaan namun data tentang prevalensi kejadian kecacingan di Indonesia masih sedikit. Penelitian ini bertujuan untuk mengetahui prevalensi dan faktor risiko kecacingan pada anjing dan kucing serta tindakan preventif untuk mencegah infeksi parasit cacing. Pengambilan data dilakukan dengan merekap rekam medik yang ada di klinik Smilevet Kelapa Gading pada Januari 2020 - Januari 2021. Seluruh data rekam medik di klinik Smilevet Kelapa Gading periode Januari 2020 - Januari 2021 berjumlah 2.259 yang terdiri atas 976 pasien anjing dan 1.283 pasien kucing. Total kasus kecacingan pada anjing dan kucing berjumlah 18 kasus. Data dianalisis secara deskriptif kuantitatif. Prevalensi kecacingan pada anjing dan kucing di klinik Smilevet Kelapa Gading pada Januari 2020 - Januari 2021 kurang dari 1\%. Spesies cacing yang teridentifikasi pada pasien kucing adalah Toxocara cati. Faktor risiko kejadian kecacingan pada anjing dan kucing dipengaruhi oleh jenis kelamin, breed, dan umur. Antelmintika yang banyak digunakan memiliki zat aktif febantel, praziquantel, dan pirantel embonate. Pemberian antelmintika secara rutin menjadi tindakan preventif untuk mencegah kejadian kecacingan pada anjing dan kucing.
\end{abstract}

Kata kunci : anjing, antelmintik, helmithiasis, kucing, faktor risiko

\begin{abstract}
Dogs and cats are animals that live alongside as pets. Helminthiasis is a common problem in pets but data about helminthiasis prevalence in Indonesia still few. This research aims to determine the prevalence and risk factor of helminthiasis in dogs and cats and preventive behaviour to prevent helminthiasis. The researcher collected data by recording medical records at Smilevet clinic Kelapa Gading in January 2020 - January 2021. All medical record data at Smilevet clinic Kelapa Gading period January 2020 - January 2021 totaled 2.259, consist 976 dogs patients and 1.283 cat patients. Total helminthiasis cases in dogs and cats were 18 cases. Data analyzed with the descriptive quantitative method. The prevalence of helminthiasis in dogs and cats at Smilevet clinic Kelapa Gading for January 2020 - January 2021 was less than $1 \%$. Helminth species that have been identified in cat patients is Toxocara cati. The risk factors for the incidence of helminthiasis in dogs and cats are influenced by sex, breed. Common anthelmintics that have been used have active substances febantel, praziquantel, and pirantel embonate. Regular administration of anthelmintics effective to prevent helminthiasis in dogs and cats
\end{abstract}

Keywords: anthelmintic, cats, dogs, helminth, risk factor 


\section{PENDAHULUAN}

Anjing dan kucing merupakan hewan yang hidup berdampingan dengan manusia. Kesehatan anjing dan kucing perlu diperhatikan karena beberapa penyakit yang menginfeksi anjing dan kucing bersifat sebagai penyakit zoonotik sehingga dapat menginfeksi manusia. Penyakit pada anjing dan kucing dapat disebabkan oleh virus, bakteri, jamur, dan parasit (Oktaviana et al. 2014). Pemeliharaan dan perawatan yang baik akan meningkatkan kesehatan anjing dan kucing. Kesehatan hewan peliharaan dapat dijaga dengan memberikan asupan gizi yang seimbang, vaksinasi, sanitasi lingkungan yang baik, dan pemeriksaan kesehatan berkala ke dokter hewan (Janis et al. 2019).

Infeksi endoparasit dapat dikelompokkan menjadi infeksi parasit cacing dan infeksi protozoa. Infeksi parasit cacing yang umum menginfeksi saluran pencernaan hewan peliharaan adalah spesies Ancylostoma spp., Dipylidium caninum, dan Toxocara spp., sementara infeksi protozoa yang umum menyerang saluran pencernaan hewan peliharaan adalah Giardia duodenalis (Pereira et al. 2016). Helminthiasis atau infeksi parasit cacing umum terjadi pada anjing dan kucing sehingga menyebabkan infeksi saluran pencernaan yang mempengaruhi pertumbuhan, produktivitas kerja, malnutrisi, dan menimbulkan masalah kesehatan (Janis et al. 2019). Beberapa spesies cacing yang bersifat zoonosis adalah Toxocara spp., Taenia spp., Dipylidium caninum, dan Dirofilaria spp (McNamara et al. 2018).

Parasit cacing dapat menyebabkan masalah kesehatan pada manusia dan hewan. Infeksi parasit cacing mempengaruhi pertumbuhan, nutrisi, produktivitas, kebuntingan, dan kualitas hidup dari hewan maupun manusia. Terapi yang diberikan berupa kemoterapi karena tidak ada vaksin yang dapat mengobati infeksi parasit cacing. Antelmintik merupakan sediaan obat yang digunakan untuk terapi kecacingan. Obat antelmintik yang digunakan untuk mengobati parasit cacing nematoda pada manusia adalah pyrantel pamoate, albendazole, mebendazole, dan levamisole.

Antelmintik untuk mengobati kecacingan pada hewan adalah febendazole, piperazine, mebendazole, albendazole, morantel, pyrantel, levamisole, ivermectin, moxidectin, monepantel, derquantel, dan emodepside. Kandungan obat antelmintik tersebut memiliki target pada ion channel protein pada nematoda (Liu et al. 2020).

\section{BAHAN DAN METODE}

\section{Waktu dan Tempat Penelitian}

Penelitian dilaksanakan pada bulan Oktober 2020 sampai dengan Februari 2021. Pengambilan data rekam medik pasien anjing dan kucing dilakukan di klinik Smilevet Kelapa Gading, Jakarta Utara.

\section{Prosedur Pengambilan Data}

Penelitian dilakukan dengan menginterpretasi data sekunder berupa rekam medik pasien anjing dan kucing yang menjadi pasien di klinik Smilevet Kelapa Gading pada periode Januari 2020 - Januari 2021. Data rekam medik disajikan dalam bentuk tabel yang memuat informasi sinyalemen dan diagnosis.

\section{Prosedur Penegakan Diagnosis}

Feses sampel diambil pada saat pemeriksaan suhu menggunakan termometer secara per rektal dan diusap pada object glass lalu ditambahkan $1-2$ tetes $\mathrm{NaCl}$ fisiologis. Kemudian ditutup dengan kaca penutup dan pemeriksaan dilakukan dibawah mikroskop dengan perbesaran lensa objektif 10x.

\section{Analisis Data}

Data hasil penelitian dianalisis menggunakan metode Chi-Square dan analisis kuantitatif untuk menghitung prevalensi kecacingan, faktor risiko, dan pemberian antelmintik sebagai tindakan preventif pada pasien anjing dan kucing di klinik Smilevet Kelapa Gading periode Januari 2020 - Januari 2021.

\section{HASIL}

\section{Prevalensi Kasus Helminthiasis}

Seluruh data rekam medik klinik Smilevet Kelapa Gading periode Januari 2020 - Januari 2021 berjumlah 2.259 kasus yang terdiri dari 976 kasus pada hewan anjing dan 1.283 kasus pada hewan kucing. Jumlah kasus Helminthiasis pada anjing dan kucing di klinik Smilevet Kelapa Gading periode Januari 2020 - Januari 2021 berjumlah 18 kasus yang terdiri dari 4 kasus helminthiasis pada anjing dan 14 kasus helminthiasis pada kucing. Jumlah kasus helminthiasis pada pasien anjing dan kucing di klinik Smilevet Kelapa Gading periode Januari 2020 - Januari 2021 berjumlah 18 kasus dari 2.259 jumlah kasus keseluruhan.

Rata - rata prevalensi helminthiasis per bulan pada pasien anjing sebesar $0.31 \%$ sedangkan pasien kucing sebesar $0.92 \%$. Tingkat prevalensi kejadian 
helminthiasis secara keseluruhan di klinik Smilevet Kelapa Gading tidak mencapai 1\%. Prevalensi kasus helminthiasis pada pasien anjing dan kucing di klinik Smilevet Kelapa Gading periode Januari 2020 - Januari 2021 disajikan pada Tabel 1.

\section{Pemeriksaan Natif Telur Toxocara spp.}

Pemeriksaan telur cacing dapat dilakukan secara natif. Pada salah satu rekam medik pasien kucing ditemukan telur cacing berbentuk bulat dengan bagian dalam dinding transparan sehingga dapat diidentifikasi telur cacing Toxocara spp. dan didokumentasikan pada Gambar 1.

\section{Persentase Faktor Risiko Helminthiasis}

Kejadian helminthiasis pada anjing dan kucing dapat dipengaruhi oleh beberapa faktor risiko. Faktor risiko yang diteliti adalah jenis kelamin, breed, dan umur hewan. Faktor risiko berdasarkan jenis kelamin tidak menunjukkan nilai yang signifikan berdasarkan uji Chi-Square baik pada anjing dan kucing. Meski demikian data menunjukkan bahwa kejadian helminthiasis baik pada anjing dan kucing dengan jenis kelamin jantan memiliki persentase kejadian yang lebih tinggi yakni sebesar $0.62 \%$ pada anjing jantan dan $1.23 \%$ pada kucing jantan dibandingkan pada anjing dan kucing berjenis kelamin betina.
Breed sebagai faktor risiko menunjukkan bahwa anjing pure breed memiliki tingkat persentase kejadian helminthiasis yang lebih tinggi yakni sebesar $0.46 \%$ dibandingkan anjing domestik dan mix breed. Sementara pada kucing, faktor breed tidak menunjukkan sebagai faktor yang signifikan dalam kejadian helminthiasis berdasarkan uji Chi-Square. Meski demikian terlihat bahwa kucing domestik memiliki tingkat persentase kejadian helminthiasis yang lebih tinggi yakni sebesar $1.27 \%$ dibandingkan kucing mix breed dan pure breed. Bedasarkan umur baik pada anjing dan kucing yang memiliki umur $\geq 1$ tahun memiliki tingkat kejadian helminthiasis yang lebih tinggi yakni sebesar $0.50 \%$ pada anjing dan $2.12 \%$ pada kucing dibandingkan dengan anjing dan kucing yang berumur $<1$ tahun meskipun secara uji statistik faktor umur terlihat tidak signifikan berhubungan dengan kejadian helminthiasis.

\section{Persentase Pemberian Antelmintik}

Pemberian antelmintik merupakan salah satu tindakan pencegahan helminthiasis yang dapat dilakukan. Rata - rata pemberian antelmintik di klinik smilevet Kelapa Gading sebesar 16,89\% pada pasien anjing dan 17,19\% pada pasien kucing. Berdasarkan persentase pemberian antelmintik tersebut tidak terlalu tinggi karena tidak mencapai $50 \%$.

Tabel 1 Prevalensi (\%) Kasus Helminthiasis Pasien Anjing dan Kucing di Klinik Smilevet Kelapa Gading Periode Januari 2020 - Januari 2021

\begin{tabular}{lcccccccc}
\hline \multicolumn{1}{c}{ Bulan } & \multicolumn{4}{c}{ Pasien Anjing } & \multicolumn{4}{c}{ Pasien Kucing } \\
\hline Januari & TS & En & He & Pv & Ts & En & He & Pv \\
Februari & 42 & 0 & 0 & 0.00 & 73 & 0 & 0 & 0.00 \\
Maret & 45 & 2 & 0 & 0.00 & 83 & 0 & 0 & 0.00 \\
April & 48 & 1 & 1 & 2.08 & 85 & 0 & 0 & 0.00 \\
Mei & 44 & 0 & 0 & 0.00 & 66 & 0 & 0 & 0.00 \\
Juni & 37 & 0 & 0 & 0.00 & 57 & 0 & 0 & 0.00 \\
Juli & 74 & 0 & 0 & 0.00 & 93 & 0 & 0 & 0.00 \\
Agustus & 85 & 0 & 0 & 0.00 & 106 & 1 & 1 & 0.94 \\
September & 85 & 1 & 0 & 0.00 & 131 & 0 & 0 & 0.00 \\
Oktober & 109 & 1 & 1 & 0.92 & 131 & 2 & 2 & 1.53 \\
November & 108 & 0 & 0 & 0.00 & 115 & 4 & 4 & 3.48 \\
Desember & 100 & 1 & 1 & 0.10 & 107 & 1 & 1 & 0.93 \\
Januari & 114 & 1 & 1 & 0.87 & 120 & 3 & 3 & 2.50 \\
\hline Rata-Rata Prevalensi & 85 & 0 & 0 & 0.00 & 116 & 3 & 3 & 2.59 \\
\hline
\end{tabular}

*Keterangan tabel : TS = Total Seluruh Pasien (N); En = Jumlah Kasus Endoparasit (n); He = Jumlah Kasus Helminthiasis (n); Pv = Prevalensi Helminthiasis Keseluruhan (\%) 


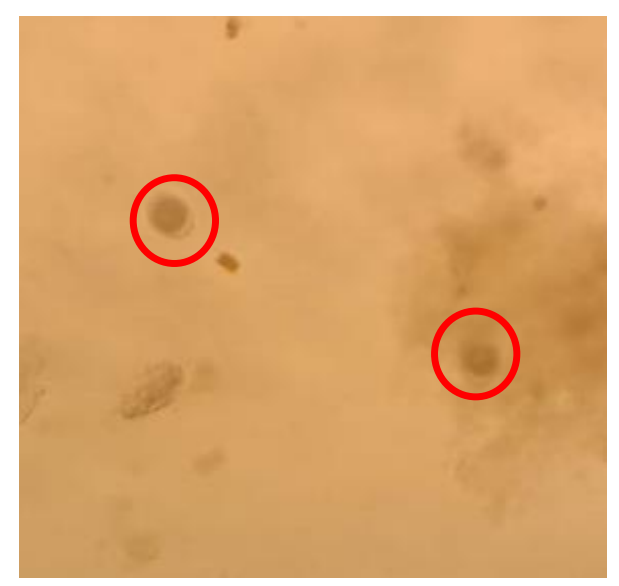

Gambar 1 Hasil pemeriksaan natif telur Toxocara spp. pembesaran objektif 10x (lingkaran merah)

\section{PEMBAHASAN}

\section{Prevalensi Kasus Helminthiasis}

Tingkat prevalensi helminthiasis pada Tabel $1 \mathrm{di}$ klinik Smilevet Kelapa Gading rendah karena tidak mencapai $1 \%$ keseluruhan kasus yang ada di Klinik Smilevet Kelapa Gading. Janis et.al (2019) menyatakan bahwa pemilik hewan yang melakukan pemeriksaan kesehatan hewan peliharaan secara berkala ke dokter hewan menjadi salah satu faktor kesehatan hewan peliharaan tetap terjaga. Sesuai dengan pernyataan tersebut, prevalensi kasus helminthiasis yang rendah pada hewan peliharaan di klinik Smilevet Kelapa Gading karena kesadaran pemilik hewan akan pemeriksaan kesehatan hewan peliharaan secara berkala.

\section{Pemeriksaan Natif Telur Toxocara spp.}

Salah satu rekam medik pasien kucing ditemukan spesies cacing Toxocara spp. Sesuai dengan penelitian Nasution (2018) mengatakan bahwa infeksi parasit pada kucing di klinik hewan yang terletak di Jakarta Utara disebabkan oleh spesies Strongyloides spp. dengan prevalensi tertinggi yakni 35,29\% , prevalensi spesies Ancylostoma spp., dan Toxocara spp. masing - masing sebesar $5,88 \%$.

Sianturi et al. (2016) menyatakan bahwa, telur cacing Toxocara spp. memiliki dinding tebal berbentuk subglobular, dinding dalam telur transparan dan terbentuk dari zat kitin, sehingga telur cacing pafa Gambar 1 melalui pemeriksaan natif telur cacing dapat diidentifikasi sebagai telur Toxocara spp.. Cacing Toxocara spp. umum menginfeksi anjing dan kucing sebagai inang definitif. Ketika anjing dan kucing dewasa teringesti telur infektif cacing Toxocara spp. maka larva menetas di dalam usus halus dan bermigrasi melalui sistem sirkulasi menuju hati, paru - paru, otot, jaringan, ginjal, dan jaringan tubuh lainnya. Larva tersebut dorman dan menjadi kista pada jaringan tubuh. Pada anjing dan kucing jantan larva menetap pada jaringan tubuh seumur hidup anjing dan kucing tersebut (Peregrine 2014).

Deteksi cacing Toxocara spp., yang telah menjadi kista pada jaringan dapat dilakukan dengan menggunakan deteksi antibodi terhadap antigen cacing Toxocara spp. dengan menggunakan enzyme linked immunosorbent assai (ELISA). Pada anjing dan kucing betina larva teraktivasi kembali pada periode akhir kebuntingan sehingga menyebabkan transmisi secara vertikal kepada anak anjing dan kucing. Cacing Toxocara canis menyebabkan infeksi melalui rute transplasental pada anak anjing sementara cacing Toxocara cati menginfeksi melalui rute transmammari. Pada anak anjing dan kucing larva menetas di usus halus anak anjing dan kucing lalu bersirkulasi hingga mencapai paru - paru sehingga dapat menimbulkan gejala klinis batuk pada anak anjing dan kucing. Larva akan berkembang menjadi cacing dewasa pada usus halus anak anjing dan kucing, telur cacing akan keluar bersamaan dengan feses anak anjing dan kucing. Telur cacing Toxocara spp. dapat teringesti oleh inang paratenik seperti ayam, tikus, dan kelinci. Namun di dalam tubuh inang paratenik larva tidak akan berkembang menjadi cacing dewasa, infeksi akan berlanjut apabila inang paratenik teringesti oleh inang definitif (Peregrine 2014). 
Manusia merupakan inang asidental cacing Toxocara spp., ketika telur infektif cacing Toxocara spp. maka larva menetas di dalam usus halus manusia dan bermigrasi menuju organ tubuh sehingga menyebabkan visceral larva migrans dan ocular larva migrans. Gejala klinis yang timbul pada manusia yang terinfeksi umumnya asimptomatis, apabila gejala klinis tampak akan terlihat adanya demam, persentase eosinofil yang tinggi, dan pembesaran hati, sehingga Toxocariasis dikategorikan sebagai zoonosis (Peregrine 2014).

Spesies cacing Toxocara spp. yang menginfeksi anjing adalah Toxocara canis dan yang menginfeksi kucing adalah Toxocara cati. Berdasar hasil penelitian, prevalensi kejadian helminthiasis yang disebabkan oleh Toxocara cati pada beberapa wilayah di Indonesia sebagai berikut, di Padang kejadian prevalensi sebesar $11,1 \%$, di Bogor dengan tingkat prevalensi 35\% dari 243 sampel, di Surabaya prevalensi sebesar 60,9\%, dan di Bali dengan tingkat prevalensi $65 \%$ dari 40 sampel yang diambil. Kejadian prevalensi yang tinggi disebabkan oleh kondisi lingkungan seperti suhu, musim dan perbedaan wilayah dapat mengoptimalkan perkembangan telur infektif. Kucing liar memiliki tingkat risiko lebih tinggi untuk menularkan infeksi dan terinfeksi telur cacing karena kontaminasi lingkungan (Suroiyah et al. 2018).

\section{Persentase Faktor Risiko Helminthiasis}

Persentase faktor risiko helminthiasis baik pada anjing dan kucing pada Tabel 2 menunjukan bahwa jenis kelamin jantan memiliki persentase helminthiasis yang lebih tinggi dibandingkan pada hewan betina. Menurut Dharma et.al (2017) anjing jantan memiliki tingkat kepekaan yang lebih tinggi terhadap kejadian infeksi parasit cacing dibandingkan dengan anjing betina karena anjing betina memiliki kadar hormon estrogen yang lebih tinggi dibandingkan dengan anjing jantan.

Hormon estrogen akan memicu sel RES (Reticulo Endothelial System) sehingga akan terbentuk antibodi terhadap parasit cacing. Menurut penelitian Murniati (2015), kucing jantan memiliki risiko 1,5 kali terinfeksi Toxocara cati dibandingkan kucing betina, hal ini disebabkan karena kucing jantan cenderung untuk lebih sering keluar rumah terutama saat musim kawin sehingga memiliki kemungkinan yang lebih tinggi tertular infeksi parasit cacing dari kucing liar yang telah terinfeksi. Berdasar kedua pernyataan tersebut dapat disimpulkan bahwa jenis kelamin jantan baik pada anjing maupun kucing dapat menjadi faktor risiko kejadian helminthiasis karena memiliki tingkat kepekaan yang lebih tinggi terhadap infeksi parasit cacing.

Tabel 2 Persentase (\%) Faktor Risiko Helminthiasis Pasien Anjing dan Kucing di Klinik Smilevet Kelapa Gading Periode Januari 2020 - Januari 2021

\begin{tabular}{ccccc}
\hline $\begin{array}{c}\text { Faktor Risiko } \\
\text { Helminthiasis }\end{array}$ & \multicolumn{2}{c}{ Pasien Anjing } & \multicolumn{2}{c}{ Pasien Kucing } \\
\cline { 2 - 5 } & Jumlah Pasien $(\mathrm{N})$ & $\begin{array}{c}\text { Persentase } \\
\text { Helminthiasis (\%) }\end{array}$ & Jumlah Pasien (N) & $\begin{array}{c}\text { Persentase } \\
\text { Helminthiasis (\%) }\end{array}$ \\
\hline $\begin{array}{c}\text { Jenis Kelamin } \\
\text { Jantan }\end{array}$ & 481 & $0.62^{\mathrm{a}}$ & 652 & $1.23^{\mathrm{a}}$ \\
Betina & 495 & $0.20^{\mathrm{a}}$ & 631 & $0.96^{\mathrm{a}}$ \\
Breed & & & & \\
Domestik & 46 & 0.00 & 789 & $1.27^{\mathrm{a}}$ \\
Mix Breed & 114 & 0.00 & 95 & $1.05^{\mathrm{a}}$ \\
Pure Breed & 816 & 0.46 & 399 & $0.75^{\mathrm{a}}$ \\
Umur* & & & & \\
$<1$ Tahun & 469 & $0.43^{\mathrm{a}}$ & 490 & $1.43^{\mathrm{a}}$ \\
$\geq 1$ tahun & 393 & $0.50^{\mathrm{a}}$ & 330 & $2.12^{\mathrm{a}}$ \\
\hline
\end{tabular}

Ket: Huruf superscript yang sama pada kolom yang sama pada setiap faktor risiko menunjukkan nilai tidak berbeda nyata berdasarkan uji Chi-Square.

*Tidak seluruh data rekam medik mencantumkan umur pasien 
Faktor risiko kejadian helminthiasis berdasar breed pada Tabel 2 menunjukan bahwa pada pasien anjing persentase helminthiasis tertinggi terjadi pada anjing pure breed. Menurut Utama et al. (2017), prevalensi kejadian helminthiasis akan lebih tinggi pada anjing pure breed dibandingkan dengan anjing mix breed dan domestik hal ini terjadi karena dipengaruhi oleh faktor immunitas dari anjing pure breed yang memiliki kekebalan tubuh yang lebih rendah dibandingkan anjing mix breed dan domestik. Anjing pure breed merupakan perkawinan anjing dengan breed yang sama sehingga akan menurunkan variasi gen pada sistem imun anjing tersebut sehingga anjing pure breed lebih rentan terhadap infeksi karena memiliki immunitas yang lebih rendah (Beuchat 2017). Hasil penelitian sesuai dengan pernyataan tersebut dan menunjukkan bahwa breed menjadi salah satu faktor risiko kejadian helminthiasis pada anjing. Pada pasien kucing, persentase helminthiasis tertinggi terjadi pada kucing domestik dibandingkan dengan kucing mix breed dan pure breed.

Berdasar latar belakang pasien kucing domestik yang mengunjungi klinik Smilevet Kelapa Gading, beberapa kucing domestik yang dibawa oleh pemilik hewan adalah kucing liar yang diselamatkan oleh pecinta hewan. Menurut Suroiyah et.al (2018) kucing liar memiliki risiko terinfeksi parasit cacing lebih tinggi melalui baik melalui interaksi antar kucing maupun akibat interaksi antar kucing dengan lingkungan yang telah terkontaminasi oleh telur cacing sesuai dengan hasil penelitian persentase helminthiasis tertinggi terjadi pada kucing domestik sehingga breed domestik pada kucing menjadi faktor risiko terjadinya kejadian helminthiasis.

Persentase faktor risiko helminthiasis berdasarkan umur menunjukan bahwa pada anjing dan kucing yang berumur $\geq 1$ tahun lebih tinggi dibandingkan anjing dan kucing berumur $<1$ tahun. Dharma et al. (2017) menyatakan bahwa pada hewan peliharaan yang berumur dibawah 6 bulan dan masih menyapih pada induk memiliki tingkat risiko terinfeksi parasit cacing lebih rendah karena sumber infeksi utama berasal dari induk secara transmammari dan transplasental, apabila induk sehat maka anak terhindar dari parasit cacing. Penularan infeksi parasit cacing pada anjing dan kucing berumur $\geq 1$ tahun terjadi apabila anjing dan kucing berkontak dengan lingkungan, makanan, bahkan anjing dan kucing lain yang telah terinfeksi oleh parasit cacing sehingga dapat disimpulkan bahwa umur menjadi salah satu faktor risiko kejadian helminthiasis pada anjing dan kucing.

\section{Antelmintik Sebagai Tindakan Preventif}

Pencegahan helminthiasis dapat dilakukan dengan beberapa cara seperti memperhatikan kesehatan hewan peliharaan, pemberian antelmintik secara berkala, dan mencegah terjadinya kontaminasi pada lingkungan tempat hewan pelihara dengan menjaga sanitasi yang baik (Saravanan et.al 2016). Berdasar Tabel 3 , persentase pemberian antelmintik di klinik Smilevet tidak terlalu tinggi karena tidak mencapai 50\% namun prevalensi kasus helminthiasis yang terjadi di klinik Smilevet Kelapa Gading rendah hal ini dapat terjadi karena tidak seluruh aktivitas pemberian antelmintik terekam oleh rekam medik, dokter hewan klinik Smilevet telah mengimbau pemilik hewan akan pentingnya pemberian antelmintik sehingga pemilik hewan memiliki kesadaran yang tinggi akan hal tersebut, dan management pemberian pakan hewan peliharaan menggunakan produk makanan khusus hewan.

Antelmintik yang digunakan di klinik Smilevet Kelapa Gading adalah antelmintik Drontal ${ }^{\circledR}$. Antelmintik tersebut mengandung bahan aktif febantel, pyrantel embonate, dan praziquantel untuk hewan anjing. Pada hewan kucing mengandung bahan aktif pyrantel embonate dan praziquantel. Menurut Pereira et al. (2016) bahan aktif antelmintik yang umum digunakan pada anjing adalah febantel, pyrantel, dan praziquantel. Sementara pada kucing adalah pyrantel dan praziquantel. Bahan aktif antelmintik tersebut akan efektif untuk mengobati infeksi parasit cacing yang disebabkan oleh cacing gelang seperti spesies Toxocara spp., cacing tambang seperti spesies Ancylostoma spp., dan infeksi cacing pita seperti spesies Dipylidium spp..

Bahan aktif febantel memiliki mekanisme kerja menurunkan pengambilan glukosa pada parasit cacing sehingga mengganggu metabolisme pembentukan energi pada parasit, bahan aktif pyrantel embonate memiliki mekanisme kerja sebagai cholinergic agonist pada parasit cacing sehingga akan menstrimulasi nicotinic cholinergic yang menyebabkan spasmus otot dan paralisis parasit cacing, sementara prazikuantel memiliki kinerja merusak intergumen parasit sehingga menyebabkan tetanik pada parasit (Liu et al. 2020). Berdasarkan pernyataan tersebut maka antelmintik yang digunakan di klinik Smilevet Kelapa Gading memiliki bahan aktif yang efektif untuk mengobati dan mencegah infeksi parasit cacing pada pasien anjing dan kucing. 
Tabel 3 Persentase (\%) Pemberian Antelmintik Pasien Anjing dan Kucing di Klinik Smilevet Kelapa Gading Periode Januari 2020 - Januari 2021

\begin{tabular}{|c|c|c|c|c|c|c|c|c|}
\hline \multirow[t]{3}{*}{ Bulan } & \multicolumn{4}{|c|}{ Pasien Anjing } & \multicolumn{4}{|c|}{ Pasien Kucing } \\
\hline & \multirow[t]{2}{*}{ TS } & \multicolumn{2}{|c|}{$\begin{array}{l}\text { Pemberian } \\
\text { Antelmintik }\end{array}$} & \multirow[t]{2}{*}{$\operatorname{Pr}$} & \multirow[t]{2}{*}{ TS } & \multicolumn{2}{|c|}{$\begin{array}{l}\text { Pemberian } \\
\text { Antelmintik }\end{array}$} & \multirow[t]{2}{*}{$\operatorname{Pr}$} \\
\hline & & SD & SP & & & SD & SP & \\
\hline Januari & 42 & 0 & 4 & $9 \cdot 52$ & 73 & 3 & 14 & 23.30 \\
\hline Februari & 45 & 2 & 9 & 24.44 & 83 & 2 & 18 & 24.10 \\
\hline Maret & 48 & 4 & 4 & 16.66 & 85 & 1 & 13 & 16.47 \\
\hline April & 44 & 3 & 4 & 15.90 & 66 & 7 & 5 & 19.70 \\
\hline Mei & 37 & 3 & 7 & 27.03 & 57 & 5 & 7 & 21.05 \\
\hline Juni & 74 & 3 & 7 & $13 \cdot 51$ & 93 & 1 & 22 & 24.73 \\
\hline Juli & 85 & 5 & 9 & 16.47 & 106 & 8 & 7 & 14.15 \\
\hline Agustus & 85 & 3 & 8 & 12.94 & 131 & 2 & 11 & 9.92 \\
\hline September & 109 & 3 & 16 & 17.43 & 131 & 10 & 21 & 23.66 \\
\hline Oktober & 108 & 7 & 12 & 17.59 & 115 & 10 & 17 & 23.48 \\
\hline November & 100 & 6 & 16 & 22.00 & 107 & 5 & 6 & 10.28 \\
\hline Desember & 114 & 3 & 12 & 13.16 & 120 & 2 & 8 & 8.33 \\
\hline Januari & 85 & 4 & 8 & 14.12 & 116 & 2 & 3 & 4.31 \\
\hline Rata - rata & 75,08 & 3,54 & 8,92 & 16,98 & 98,69 & 4,46 & 11,69 & 17,19 \\
\hline
\end{tabular}

Efektivitas antelmintik tentunya akan dipengaruhi dengan jangka waktu pemberian antelmintik pada hewan peliharaan. Menurut Stull et al. (2007), anak anjing yang berumur 4,6, dan 8 minggu dan anak kucing berumur 3,5,7,dan 9 minggu harus diberikan antelmintik untuk mencegah infeksi oleh parasit cacing Toxocara canis, Toxocara cati, dan Ancylostoma caninum. Pada anjing dan kucing dewasa pemberian antelmintik minimal 2 kali dalam setahun, namun pemberian antelmintik juga disesuaikan dengan lingkungan hewan peliharaan.

Dari hasil penelitian ini dapat disimpulkan prevalensi kecacingan pada anjing dan kucing di klinik Smilevet Kelapa Gading periode Januari 2020 - Januari 2021 rendah. Faktor risiko jenis kelamin, breed, dan umur mempengaruhi kejadian helminthiasis. Pemberian antelmintik dapat menjadi tindakan preventif untuk mencegah helminthiasis.

"Penulis menyatakan tidak ada konflik kepentingan dengan pihak-pihak yang terkait dalam penelitian ini".

\section{DAFTAR PUSTAKA}

Beuchat C. 2017. Inbreeding and the immune system : unintended consequences. [diakses 2021 May 7]. https://www.instituteof caninebiology.org/blog/inbreeding-and-the-immune-systemunintended-consequences.

Dharma IPPN, Oka IBM, Dharmawan NS. 2017. Prevalensi infeksi cacing Ancylostoma spp. Pada anjing di kawasan wisata di Bali. Indonesia Medicus Veterinus. 6(3):230 - 237.

Janis DWN, Deta HU, Winarso A. 2019. Perubahan bobot badan anak anjing lokal terinfeksi Toxocara canis setelah pemberian pyrantel pamoat di Kota Kupang. Jurnal Veteriner Nusantara. 2(2): 49- 59 .

Liu M, Panda SK, Luyten W. 2020. Plant - based natural products for the discovery and developmment of novel anthelmintics against nematodes. Biomolecules. 10 (426): 1- 22.

Mcnamara J, Drake J, Wiseman S, Wright I. 2018. Survey of European pet owners quantifying endoparasitic infection risk and implications for deworming recommendations. Parasites and Vectors. $11(571): 1-12$. 
Murniati. 2015. Prevalensi dan faktor risiko infeksi cacing zoonotik pada kucing peliharaan di kota Bogor [Tesis]. Bogor : Institut Pertanian Bogor.

Nasution AYA. 2018. Kajian parasitosis pada anjing dan kucing peliharaan yang datang ke klinik hewan di Jakarta Utara [Tesis]. Bogor : Institut Pertanian Bogor.

Oktaviana PA, Dwinata M, Oka IBM. 2014. Prevalensi infeksi cacing Ancylostoma spp. Pada kucing lokal (Felis catus) di kota Denpasar. Buletin Veteriner Udayana. 6(2): 161- 167.

Peregrine AS. 2014 Okt. Roundworms in small animals. [diakses 2021 May 7]. https://www.msdvet manual. com/digestive-system/gastrointestinalparasites-of-small-animals/roundworms-in-smallanimals.

Pereira A, Martins A, Brancal H, Vilhena $H$, Silva $P$, Pimenta P, Diz-lopes D, Neves N,Coimbra M, Alves CA, et.al. 2016. Parasitic zoonoses associated with dogs and cats : a suvey of Portuguese pet owner's awareness and deworming practices. Parasites and Vectors. 9(245): $1-9$.

Regina MP, Halleyantoro R, Bakri S. 2018. Perbandingan pemeriksaan tinja antara metode sedimentasi biasa dan metode sedimentasi formolether dalam mendeteksi soil-transmitted helminth. Jurnal Kedokteran Diponegoro. 7(2): $527-537$.

Saravanan M, Sarma K, MOndal DB, Kumar MR, Vijayakumar H. 2016. Concomitant infestation of
Toxocara cati and Ancylostoma tubaeforme in a mongrel cat. J. Parasit dis. 20(1) : 205- 107.

Sianturi CLJ, Priyanto D, Astuti NT. 2016. Identifikasi telur Toxocara cati dari feses kucing di kecamatan Banjarnegara, Bawang, dan Purwareja Klampok kabupaten Banjarnegara. Medsains. 2(11): $25-30$.

Sinaga BC, Hariani N. 2019. Prevalensi dan intensitas ektoparasit pada anjing peliharaan (Canis familiaris) di Kalimantan Timur, Indonesia. Jurnal Bioterdidik. 7(5): 43-52.

Stull JW, Carr AP, Chomel BB, Berghaus RD, Hird DW. 2007. Small animal deworming protocols, client education, and veterinarian perception of zoonotic parasites in western Canada. Can Vet Journal. 48: $269-276$.

Suroiyah FA, Hastutiek P, Yudhana A, Sunarso A, Purnama MTE, Praja RN. 2018. Prevalensi infeksi Toxocara cati pada kucing peliharaan di Kecamatan Banyuwangi. Jurnal Medik Veteriner. 1(3): $99-104$.

Utama KJ, Oka IBM, Dharmawan NS. 2017. Prevalensi infeksi cacing Toxocara canis pada anjing di kawasan wisata di Bali. Indonesia Medicus Veterinus. 6(4) : $288-295$.

Wahyudi NT, Suwanti LT, Kusnoto, Mumpuni S, Yudaniyanti IS, Mafruchati M. 2017. Prevalence of helminth eggs in cat feces contaminating public areas in Surabaya. Indonesian Journal of Tropical and Infectious Disease. 6(6): 154 - 159. 